\title{
Socioeconomic Contributions of Neglected and Underutilized Species to Livelihood Security in Rural Southwest Nigeria: Thaumatococcus Danielli as a Test Case
}

\author{
Isaac B. Oluwatayo \\ Department of Agricultural Economics and Animal Production, \\ University of Limpopo, Sovenga 0727, South Africa. \\ Email: iboluwatayounad@yahoo.com
}

Ayodeji. O. Ojo

Department of Agricultural Economics, University of Ibadan, Nigeria Email: ayodejiojo7591@gmail.com

\section{Doi:10.5901/mjss.2014.v5n27p311}

\section{Abstract}

\begin{abstract}
There is no gainsaying the fact that Nigeria is blessed with vast human and material resources. Despite this, it is very appalling to know that a sizeable number of inhabitants of the country have continued to face untold hardship arising from dwindling incomes, rising poverty levels and other forms of socioeconomic deprivations. This is not unconnected with inadequacy of information and lack of awareness on and accessibility to livelihood-enhancing opportunities available in different regions of the country. The result presented here relied on data collected from a random sample of 320 households engaged in the production, processing and marketing of Thaumatococcus danielli (an example of neglected and underutilised specie - NUS) from three communities in rural Southwest Nigeria. Data analysis revealed average age of respondents to be 63 years with mean household size of 7 . Distribution of respondents by educational level showed that only about one-quarter had tertiary education with more females engaged in the processing and marketing of Thaumatococcus danielli products. On the economic contributions of Thaumatococcus danielli to livelihood security of respondents in the study area, about two-third (68.3 percent) of them are engaged in the production, processing and marketing of this particular NUS either on full-time or part-time basis thereby depicting its relative importance to other income generating activities/ventures in the study area. In fact, a further analysis of the data revealed that the income generated from Thaumatococcus danielli amounted to between 57-73 percent of the total income of respondents harnessing it However on the determinants of harnessing Thaumatococcus danielli as a source of livelihood; age ( $p<0.05)$, gender $(p<0.00)$, educational status $(p<0.01)$, poverty status $(p<0.05$, participation in off-farm activity $(p<0.05)$, extension contact $(p<0.00)$ and access to market $(p<0.10)$ were very significant. While the coefficients of educational status, poverty status and extension contact were negative, those of age, gender, access to market were positive. It is therefore suggested that effort should be geared at building capacity of respondents through education to enhance their earning potentials and adoption of new skills. Awareness should be created on untapped livelihood-enhancing opportunities available in the study area so as enhance the income of residents and reduce poverty.
\end{abstract}

Keywords: Income, Livelihood, NUS, Southwest Nigeria, Thaumatococcus danielli

\section{Introduction/Statement of the Problem}

There is no gainsaying the fact that Nigeria is blessed with vast human and material resources. As one of the most populous countries in Africa, Nigeria has a landmass of over 923,768 square kilometers including about 13,000 square kilometers of water; enclosed within latitudes $4^{\circ} 16^{\prime}$ North and $13^{\circ} 52^{\prime}$ North of the equator and between longitudes $2^{\circ} 49^{\prime} \mathrm{E}$ and $14^{\circ} 37^{\prime}$ East of Greenwich Meridian with a population of $140,003,542$ and a population growth rate of 3.2 percent annually (NBS, 2007). Associated with the varied ecological zones is an array of plant and animal species. There are 7,895 plant species from 338 families and 2,215 genera that have been identified in Nigeria (FGN, 2006; USAID, 2008).

In spite of these abundant resources, the inhabitants of the country have continued to face untold hardship arising from dwindling incomes, rising poverty levels and other forms of socioeconomic deprivations. Meanwhile, it has been established that about 70 percent of Nigerians reside in the rural areas with agriculture providing livelihood opportunities for over three-quarter of them (NBS, 2006; Oluwatayo, 2008). Yet, a sizeable number of available plant species in these 
rural communities which ought to provide livelihood opportunities and enhance the wellbeing of rural folks are either neglected or underexploited. This is not unconnected with inadequate information on the benefits inherent in these natural endowments. These species of plants are neglected by scientific research and agricultural policies, and therefore remain underutilized (FMEnv, 2008).

However, these Neglected or Underutilized Species (NUS) can be an important source of livelihood to a number of unemployed people living in rural areas through provision of cash income and one of such plant specie in Nigeria is Thaumatococcus danielli (Benn). Thaumatococcus danielli is thus a non timber forest species (Borokini et al, 2010) that can contribute to the rural economy of Nigeria but whose potentials has not been fully exploited. It is a multi-purpose perennial herb that offers a wide assortment of uses for its leaves, fruits, stalks and roots (Arowosoge and Popoola, 2002). The fruit for instance was discovered to contain a sweet protein called thaumatin (Edens et al, 1982). The fruit was found to be 3000 times sweeter than sucrose, thus making thaumatin the sweetest natural substance known to man. The leaves on the other hand were found to be useful as wrapping material while the stalk is processed (weaved) into mats used in many countries of the world.

From the foregoing and considering the usefulness of Thaumatococcus danielli in terms of its versatility, a research into its income generating potentials among households in rural Southwest Nigeria could be a right step in the right direction especially now that there is massive unemployment and over-utilization of conventional and well known species of plants in Nigeria. Thus, the research outcome will help provide an alternative income generating venture that will assist in finding solutions to the lingering problem of dwindling incomes and uncertainties pervading in the study area and Nigeria in general.

\section{Literature Review}

Agriculture is known to be the mainstay of the Nigerian economy before the discovery of oil in 1970s. Despite the heavy dependence on crude oil, agriculture still contributes significantly to the nation's GDP. About seventy percent of Nigerians are employed directly or indirectly by agriculture. Even more than $50 \%$ of the agricultural labour force dwells in the rural area. The sector is bedeviled by age-long neglect, adverse climate change impacts, traditional mode of farming and low level of technology among others (Oluwatayo, 2009). Poor agricultural output and soaring poverty rates has posed food security challenges on Nigeria such that almost 70\% of Nigerians are food insecure today (Walkenhost, 2007, Obayelu, 2010, Oluwatayo, 2010).

Thaumatococcus danielli belongs to the family Maranthacae and is found in hot humid, humid tropical rainforests and coastal area of West Africa. It is found in commercial quantities in the southern parts of Ghana, Cote d'voire and Nigeria. The perennial plant is seasonal and as such flowers between July and October annually. After flowering, the fruit forms, matures and ripens between January and April. The fruits grow close to the soil with short stalks usually covered with plan debris (Yeboah et al., 2002, Ojekale et al., 2007). Thaumatococcus danielli also called 'ewe eran' is a tropical plant found in south-western, Nigeria. When matured, the stalk is used for mat weaving, which used to be the major economic activity of communities where it is found.

Mats are thick and fabrics made from plants such as this plant, raffia palm etc used as beddings, fans and in the production of cane chairs .It grows freely in Ogotun Ekiti (Ekiti State), Ikeji lle and Ipetu ljesa (both in Osun State) and some parts of Oyo State but there is evidence from literature that it can be cultivated on the farm. This plant can be produced into mats by cutting (and other farm level activities), smothering, drying, dyeing and finally weaving. Therefore, the process is highly stressful because it is energy sapping and time consuming. The cultivation of Thaumatococcus danielli is rainfed, exposing it to weather variations hence the seasonality of the plant.

In the past, cultivation and processing of this plant into mats was the predominant occupation of women in Ogotun Ekiti, Ikeji Ile Ipetu ljesa and Oyo. These were integrated into their culture as they are referred to as 'eleni' meaning mat weavers. In the wake of civilization and demand from other agribusinesses, Thaumatococcus danielli production and consequently mat weaving became threatened. Over the years, there has being a consistent decline in the production of this plant consequently leading to reduction in the amount of products. For instance, the producers are ageing with the youths being indifferent about the enterprise (Boyinde, 2012). It has been reported in literature that the cultivation of this plant and consequent processing into mats is capable of reducing poverty if developed.

Production of mat is carried out by weaving Thaumatococcus danielli after drying through a process called plaiting. According to Oluwatayo (2010), the bulk of agricultural production, processing and marketing is usually done by women. The processing of this plant is carried out by women in rural areas as a means of sustaining and supplementing family income. However, the men are involved in the cultivation and harvesting of the Thaumatococcus danielli leaves. The production of fans for traditional chiefs from the plant is handled by men and experienced women alike (Irivwieri, 2009). 
Locally, Thaumatococcus danielli fruits are used for sweetening palm wine and sour foods. The aril of this plant is said to contain thaumatin; a non-toxic substance 1600times sweeter than sucrose which is used to sweeten beverages, desserts, bubble gums among others (Yeboah et al., 2002, NAGRAB, 2008, Eniayeju, 2010). The plant is however undercultivated and underutilized in Nigeria and as such cannot fulfill local requirements and consequently industrial demand, given the current level of production. All parts of Thaumatococcus danielli are useful, a feature which qualifies it as an economic plant. The by-product of mat weaving is used for producing local sponge for bathing. The leaves are used for thatching roofs and it can last for 2years. The leaves are noted for wrapping of different kinds of food. It can be used for wrapping unprocessed food like meats, kolanuts, bitter cola etc.; semi-processed foods like locust beans and processed foods like pounded yam, Amala (cooked yam flour), pap, beans among others (Ojekale et al., 2007, AdebisiAdelani et al., 2010, Eniayeju, 2010).

\section{Materials and Methods}

\subsection{Study area and sampling method}

The study was conducted in Southwest Nigeria. The region is composed of six states - Ekiti, Lagos, Ogun, Ondo, Osun and Oyo. Primary data were collected from rural households in the region using structured questionnaire. Information contained in the questionnaire included socioeconomic characteristics of these households, socio-cultural and environmental background, different activities and enterprises engaged in, other livelihood activities, uses of Thaumatococcus danielli and its importance in the study area. Three States were randomly selected in the region and one community/village from each state with known availability of the plant was covered and a total of 320 respondents were administered questionnaire in the survey.

\subsection{Methods of data analysis}

Analytical techniques employed include descriptive statistics (tables, means and frequencies e.t.c), poverty index and logit regression model. While the descriptive statistics was used to analyse respondents' socioeconomic variables, the poverty index was employed to ascertain the poverty status of the respondents in the study area. However, a logit regression model was used to ascertain the determinants of harnessing Thaumatococcus danielli as a source of livelihood.

In using the poverty index, the two-third mean per capita expenditure was employed as the benchmark to categorise the respondents into the poor and non-poor class. This is expressed as:

Total consumption expenditure (TCE) $=$ Total expenditure on food and non-food items

Mean TCE $=$ TCE/Number of respondents under study

Poverty benchmark $(\mathrm{PB})=2 / 3 \times$ Mean TCE $=$ Poverty line

Thus, any respondent whose PE is equal to or greater than poverty line is regarded as being non-poor (1). However, those with poverty benchmark lower than the poverty line are regarded as being poor (0).

The logit model was employed to find the probability that a given respondent has harnessed Thaumatococcus danielli, knowing that the probability of harnessing it will either be 1 or 0 . Thus:

$$
\begin{aligned}
& P(x)=y=\frac{1}{1+\exp (-\beta 0-\beta 1 x)} \\
& \text { Logit }(y)=\log (y /(1-y), \\
& \text { Logit }(P(x))=\log (P(x) / 1-P(x))=\beta_{0}+\beta_{1} x
\end{aligned}
$$

The logistic regression model describes the relationship between dichotomous response variable for instance $Y$, coded to take the value of 1 or 0 and $k$ explanatory variables $x_{1}, x_{2}, \ldots . X_{k} . Y$ is a binary variable with Bernoulli distribution with parameter $p=P(Y-1)$, that is, $p$ is the probability of success for the explanatory variables.

$$
\mathrm{Pi}=\frac{1}{1+\exp \left(-\beta 0-\sum_{j}^{k}=1 \beta j x i, j\right)}
$$

Where:

$\mathrm{Pi}=\log$ of odd ratios

$\mathrm{Pi}=1$ if a respondent harnesses Thaumatococcus danielli as a livelihood source) and zero otherwise.

The dependent variable $(\mathrm{y})$ which is:

$\mathrm{Pi}=1 / 0=\mathrm{P} i$ In (if a respondent harnesses Thaumatococcus danielli as a livelihood source)

$\mathrm{Pi}=0 / 1=\mathrm{Pi}$ In (if a household does not harness Thaumatococcus danielli as a livelihood source)

Explanatory variables included in the model are: 


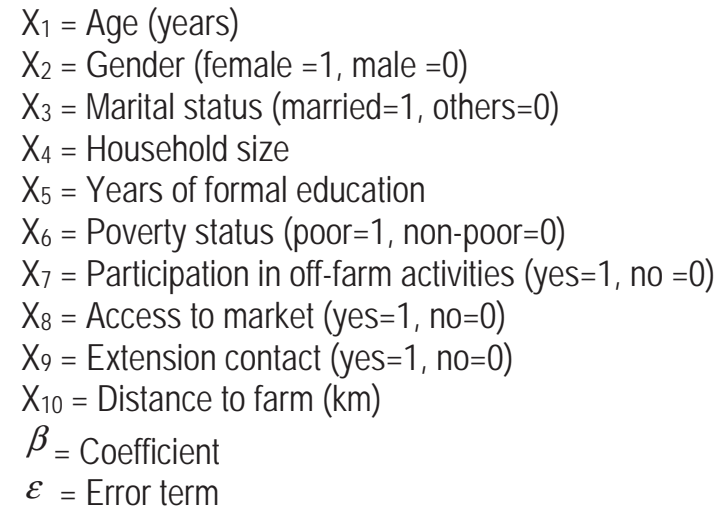

\section{Results and Discussion}

\subsection{Socioeconomic characteristics of respondents}

A number of respondents' socioeconomic variables as depicted in Table 1 were considered in this study. Some of these variables include age, gender, marital status, household size, educational status primary occupation and extension contact. Analysis of data revealed that average age of respondents was 63 years with a mean household size of 7 , an indication that most of those harnessing Thaumatococcus danielli are relatively still in their active working age. Meanwhile, the average household size showed that respondents have a fairly large household size hence the low income per capita and high level of poverty in the study area. The result further showed that there were more married respondents than single, divorced or widowed respondents. However, distribution of respondents by educational level showed that only about one-quarter (25.3\%) had tertiary education and about one-third (35.3\%) had no formal education with more females (71.9\%) engaged in the processing and marketing of Thaumatococcus danielli products. Also, more than two-third (8.4\%) of those surveyed had farming as their main occupation with less than $10 \%$ of them engaged by the government as civil servant.

Table 1: Distribution of respondents by socioeconomic characteristics

\begin{tabular}{|c|c|c|}
\hline Variable & Frequency & Percentage (\%) \\
\hline Age & & \\
$\geq 30$ & 26 & 8.1 \\
$31-40$ & 49 & 15.3 \\
$41-50$ & 83 & 25.9 \\
$51-60$ & 127 & 39.8 \\
$\leq 61$ & 35 & 10.9 \\
Gender & 123 & 38.4 \\
Male & 197 & 61.6 \\
Female & 21 & 6.5 \\
Marital status & 183 & 57.2 \\
Single & 69 & 21.6 \\
Married & 47 & 14.7 \\
Divorced & & \\
Widowed & 113 & 35.3 \\
Educational level & 74 & 23.1 \\
No formal education & 52 & 16.3 \\
Primary & 81 & 25.3 \\
Secondary & & \\
Tertiary & 52 & 16.3 \\
Household size & 83 & 25.9 \\
$1-3$ & 101 & 31.5 \\
$4-6$ & 48 & 15.0 \\
$7-9$ & 36 & 11.3 \\
10-12 & & \\
$\geq 13$ & $0-$ & \\
\hline
\end{tabular}




\begin{tabular}{|c|c|c|}
\hline Primary occupation & 219 & 68.4 \\
Farming & 43 & 13.4 \\
Trading & 36 & 11.3 \\
Artisan & 17 & 5.3 \\
Civil service & 05 & 1.6 \\
Others & 320 & 100 \\
Total & & \\
\hline
\end{tabular}

\subsection{Economic contribution of Thaumatococcus danielli to respondents' livelihood security}

On the economic contributions of this crop to livelihood security of respondents, about two-thirds (68.4 percent) of them are engaged in the production, processing and marketing of this particular NUS either on a full-time or part-time basis thereby depicting its relative importance to other income-generating activities/ventures in the study area. In fact, a further analysis of the data revealed that the income generated from Thaumatococcus danielli amounted to between 57-73 percent (constituting an average of N104, 994.00 of the total income of respondents harnessing it as shown in Table 2. Therefore, this value is an indication of the share of income generated from Thaumatococcus danielli alone in comparison with the income generated from other source of livelihood in the study area. Thus, this NUS remains one of the most important source of livelihood to residents of the study area and most especially, the women.

Total consumption expenditure (TCE) $=$ Total expenditure on food and non-food items $=$ N153,500.00

Mean TCE $=$ TCE/Number of respondents under study $=$ N153,500.00/320 $=$ N479.6875

Poverty benchmark $(P B)=2 / 3 \times$ Mean TCE $=$ Poverty line $=2 / 3 \times 479.6875=$ N319.7917

Thus, any respondent with consumption expenditure below N319.7917 is regarded as being poor but those with consumption expenditure equal to or above N319.7917 are regarded as being non-poor.

Table 2: Share of income from Thaumatococcus danielli to other income sources

\begin{tabular}{|c|c|c|c|}
\hline Variable & $\begin{array}{c}\text { Number of } \\
\text { respondent }\end{array}$ & $\begin{array}{c}\text { \% share of } \\
\text { respondent }\end{array}$ & $\begin{array}{c}\text { Share of income (N) from } \\
\text { Thaumatococcus danielli }\end{array}$ \\
\hline Farming & 219 & 68.4 & $104,994.00$ \\
Trading & 43 & 13.4 & $20,569.00$ \\
Artisan & 36 & 11.3 & $17,345.50$ \\
Civil service & 17 & 5.3 & $8,135.50$ \\
Others & 05 & 1.6 & $2,456.00$ \\
Total & 320 & 100 & $153,500.00$ \\
\hline
\end{tabular}

\subsection{Determinants of harnessing Thaumatococcus danielli as livelihood security source}

The result of the logistic model employed to ascertain the determinants of harnessing this NUS as a source of livelihood sources showed that the coefficients of age, gender, household size and access to market were positive were positive and significant at $p<0.05, p<0.00, p<0.10$ and $p<0.10$ respectively. In other words, the higher the value of these variables, the more the likelihood of the respondents harnessing Thaumatococcus danielli as a source of livelihood. Thus in the case of access to market and extension contact, the more the accessibility of those harnessing this NUS to market and extension contact, the more their likelihood of harnessing it. On the other hand, the coefficients of educational status, poverty status, extension contact and participation in off-farm activities were negative and significant at $p<0.01, p<0.05$, $p<0.00$ and $p<0.05$ respectively. Therefore, an increase in the value of these variables has the likelihood to reduce harnessing this NUS as a livelihood source. In other words, the higher the educational status and the higher the participation in off-farm activities, the lower the likelihood of these respondents harnessing Thaumatococcus danielli as a livelihood source in the study area. 
Table 3: Result of logistic regression on the determinants of harnessing Thaumatococcus danielli as livelihood security source

\begin{tabular}{lccc}
\hline Variable & Coefficient & Standard error & Marginal effect \\
\hline Age & $0.0980^{\star *}$ & 0.0431 & 0.0310 \\
Gender & $0.1572^{\star \star \star}$ & 0.0403 & 0.1500 \\
Marital status & -2.3996 & 1.8815 & -0.1167 \\
Household size & $0.1493^{\star}$ & 0.0821 & 1.0030 \\
Education status & $-0.9044^{\star \star *}$ & 0.3501 & -1.3556 \\
Poverty status & $-0.0148^{\star \star}$ & 0.0065 & -0.1702 \\
Participation in off-farm & $-0.2107^{\star \star}$ & 0.0924 & -0.578 \\
Access to market & $0.2247^{\star}$ & 0.1202 & 0.6001 \\
Access to extension serv. & $0.8905^{\star \star *}$ & 0.3301 & 0.0773 \\
Distance to farm & 1.0153 & 0.0132 & 0.5619 \\
Constant & $3.2011^{\star \star}$ & 1.2206 & \\
\hline
\end{tabular}

Log likelihood $=-189.11$, Chi square $=53.84$, Number of observations $=320$, Pseudo $R^{2}=0.213$,

${ }^{* * *}$ Coefficient significant at $1 \%,{ }^{* *}$ Coefficient significant at $5 \%,{ }^{*}$ Coefficient significant at $10 \%$

\section{Summary, Conclusion and Recommendations}

This study examined the contributions of Thaumatococcus danielli to livelihood security in rural Southwest Nigeria. Findings from the study showed that the bulk of the income realised by the respondents were generated from this particular NUS either from its production, processing or marketing of Thaumatococcus danielli products. Again, while poverty status, educational status and participation in off-farm activities were important correlates of harnessing this crop, a gender analysis of those harnessing it showed that there were more females than males. Going by the findings from this study, it is therefore recommended that:

1. Effort should be geared towards building the capacity of respondents through education so as to enhance their earning potentials and adoption of new skills that will be used in improving the production, processing and marketing of Thaumatococcus danielli's products.

2. Also, awareness should be created on the untapped livelihood-enhancing opportunities (other NUS species) available in the study area so as to enhance the income of residents and reduce the rising poverty in the study area.

3. Increase in extension contact to the farmers will not only enhance improvement in its productive but could also assist in showcasing the income-generating and poverty-reducing potential of Thaumatococcus danielli and other useful NUS in the study area for better profit and utilization.

\section{References}

Adebisi-Adelani O., Adeoye I. B., Olajide-Taiwo F. B., Usman J. M, Agbarevoh P., Oyedele, O. O. 2010. Gender Analysis of Production, Potential and Constraints of Thaumatococcus danielli in Ekiti State. Published in Continental Journal of Agricultural Science, Issue 4, ISSN: 2141-4203, pp54-59.

Arowosoge, O. G. E., Popoola, L. 2002. Economic Analysis of Thaumatococcus danielli (Benn), Miraculous Berry in Ekiti State, Nigeria. International Journal of Food, Agriculture and Environment, 4 (1): 264-269.

Borokini, T. I., A. U. Okere, A. O. Giwa, B. O. Daramol, Odofin, W. T. 2010. Biodiversity and Conservation of Plant Genetic Resources in Field Genebank of the National Centre for Genetic Resources and Biotechnology, Ibadan, Nigeria. International Journal of Biodiversity and Conservation, Vol. 2(3): 37-50.

Boyinde O. K. 2012. Ipetu-ljesa and the Extinction of Mat Making; retrieved from www.oluwatomilolakboyindeblogspot.in-ipetu-ljesa-andextinction-of-mat.html on the $4^{\text {th }}$ of June, 2013.

Edens L., Heslinga L., KWK R, Ledeboer A. M, Maat J, Toonen M. Y., Viser C, Verrips C. T 1982. Cloning of DNA encoding the Sweettasting plant protein thaumatin and its expression in Escherichia coli gene. 18 (1):1-12.doi; 10.1016/0378-111, 9 (82) 900506.PMID 7049841.

Eniayeju A. A. 2010. Women and Sustainable Development in Nigeria: Empowering the Girl-Child Mathematically, pp5-10.

(FGN) Federal Government of Nigeria, 2006. Draft Report. National Capacity Needs Self-assessment for Environmental Management. Federal Ministry of Environment, Abuja, Nigeria.

FMEnv. 2008. National Biodiversity Strategy and Action Plan, Federal Ministry of Environment, Abuja.

Irivwieri, G. O. 2009. Arts and Crafts as Springboard for Sustainable Development and Industrialization in Nigeria. Published in International Journal of Creativity and Technical Development, volume 1, p5. 
National Bureau of Statistics, NBS. 2006. The Nigerian Statistical Fact Sheet on Economic and Social Development, Abuja, November, 2006.

National Bureau of Statistics, NBS. 2007. 2006 Population Census. Available at www.nigerianstat.gov.ng.

National Centre for Genetic Resources and Biotechnology, NAGRAB Ibadan, 2008. Plant Genetic Resources for Food and Agriculture (1996-2008), p16.

Obayelu, A. E. 2010. Classifications of Households into Food Security Status in the North-Central Nigeria: An application of Rasch Measurement Model. Published in Journal of Agricultural Biological Sciences. Issue 5(3).

Ojekale A. B., Makinde S. C. O., Osileye, O. 2007. Phytochemistry and antimicrobial evaluation of Thaumatococcus danielli, Benn. (Benth.) leaves. Published in the Nigerian Food Journal, Volume 25, ISSN 0189-7241, pp1-5.

Oluwatayo, I. B. 2008. Explaining Inequality and Welfare Status of Households in Rural Nigeria: Evidence from Ekiti State. Humanity and Social Sciences Journal, 3 (1): 70-80, 2008.

Oluwatayo, I. B. 2009. Vulnerability and Adaptive Strategies of Staple Food Crop Farmers to Seasonal Fluctuations in Production and Marketing in Southwest Nigeria contribution to Seasonality Revisited International Conference Institute of Development Studies, UK. P2

Oluwatayo, I. B. 2010. Gender Considerations in Decision Making in Rural Nigeria: Implications on Households' Food Security in Ekiti State, pp2-4.

United States Agency for International Development (USAID) 2008. Nigeria Biodiversity and Tropical Forestry Assessment. Published for USAID by Chemonics International Inc. June.

Walkenhorst, P. 2007. Distortions to Agricultural Incentives in Nigeria. Working paper 37 submitted to the World Bank.

Yeboah S. O., Hilger T. H., Krochcel, J. 2002. Thaumatococcus danielli (Benn.) Benth.-a Natural Sweetener from the Rain Forest Zone in West Africa with Potential for Income Generation in Small Scale Farming, pp1-4. 